\title{
WHERE INNER-CITY STUDENTS LIVE VERSUS HOW THEY LEARN
}

\section{NORMAN A. NEWBERG $†$}

Dr. Orfield is a proponent of an influential, but flawed approach to the problems of the poorest minority children. In a recent article, he uses a medical analogy to explain the inadequacy of the current treatment plans for school segregation. He asserts:

To understand and to produce lasting change in metropolitan school segregation it is essential to deal with housing issues. A school desegregation plan is like a major operation on a longestablished cancer. The benefits of the surgery greatly diminish and the risks soar if it is undertaken without understanding the body's structure [or] if the operation ends before the cancer is completely removed. ${ }^{1}$

Orfield sees segregation as the "cancer" and the spread of the disease as linked to the interaction between housing and schools. He asserts that integrated housing can produce integrated schools and, by extension, quality education for poor minorities. Thus, excising the cancer of segregated housing eliminates the spread of the disease in schools.

Although the rhetorical impact of the cancer analogy endures, it is, for purposes of effective school reform, no more instructive today than it was twenty-five years ago. ${ }^{2}$ In 1970, I coauthored an article commissioned by the U.S. Office of Education entitled That's

† Senior Fellow, Graduate School of Education, University of Pennsylvania, and Executive Director, Say Yes to Education Foundation. I am grateful to my son, Joshua Newberg, for his helpful comments.

' Gary Orfield, Housing as a Justification for Resegregating Schools: Consequences of Changing Judicial Interpretations 87 (April 1995) (unpublished manuscript, on file with author) [hereinafter Orfield, Housing]; see Gary Orfield, Housing and the Justification of School Segregation, 143 U. PA. L. REV. 1397 (1995) [hereinafter Orfield, Abstract] (summarizing as an abstract Orfield's unpublished paper, but not presenting the cancer metaphor).

2 See SuSAN SONTAG, Illness as Metaphor, in ILlNESS AS METAPHOR AND AIDS AND ITS METAPHORS 1, 85 (1978) (analyzing, as a way of explaining perplexing social phenomena in the twentieth century, the inappropriate use of diseases such as cancer, and stating that ' $[t]$ rying to comprehend 'radical' or 'absolute' evil, we search for adequate metaphors. Only in the most limited sense is any historical event or problem like an illness."). 
Not a Cancer; That's a School System. ${ }^{3}$ In the opening paragraph, we state:

There is a great deal of talk these days about the futility of putting band-aides [sic] on the cancers infecting the school system. Such talk is misleading; the implication is that a doctor can come in, and if not dole out band-aides [sic], then do some drastic surgery, and all will be well. ... We find it more helpful and more accurate to avoid thinking about cancers and surgery in education. ... We believe our job is to work directly with the assumptions and applications of that system-changing them so that they allow students, teachers, and administrators to find greater freedom, joy, and usefulness in the learning experience. ${ }^{4}$

Because neither ineffective school systems nor segregated housing are like cancers and will not respond to the surgeon's knife, we are still left with a basic question: What is the best allocation of ameliorative resources in treating a systemic problem? Orfield assures his readers that the problem is solved by implementing various strategies to desegregate housing. Such strategies may have merit as vehicles for expanding the housing options of urban minority families and for promoting the development of racially and/or ethnically diverse neighborhoods. Housing has, moreover, among its attractions as a focus for reform, its amenability to quantitative measurements of "concrete" inputs and outputs. But whatever the merits of housing desegregation, it requires an Olympian leap of faith to expect that such programs will address the pervasive dysfunction of the largest inner-city public school systems. The schools themselves must change, and change dramatically, and equally important, meaningful economic opportunities must be developed. Poor minority students are best served when a set of interventions addresses the ecology of their situation. ${ }^{5}$ Housing, then, is but one element, along with restructuring of schools and economic opportunity, that together promise a better life for innercity minority students and for the communities in which they live.

${ }^{3}$ Terry Borton \& Norman A. Newberg, That's Not a Cancer; That's a SCHOOL SYSTEM 1 (U.S. Office of Educ. No. OEC-07-5062, 1970).

4 "Public Education Can Work," GSE NEWSLETTER (University of Pa. Graduate School of Educ., Phila., Pa.), Fall-Winter 1982, at 1 (quoting That's Not a Cancer; That's a School System).

${ }^{5}$ See generally URIE BRonfenbrenner, The Ecology OF HuMAN DEvelopMENT: EXPERIMENTS BY NATURE AND DESIGN 3 (1979) (providing a theoretical perspective for research in human development based on the ecological environment). 


\section{DESEGREGATION AND ACADEMIC ACHIEVEMENT}

As a matter of principle, I agree with the advocates of housing desegregation that citizens must have a right to live where they wish. But the policy choices that follow from the principle are, by no means, self-evident. Orfield, who is among the most distinguished voices for housing desegregation's transformative potential, talks about moving toward "natural integration." In my experience, I have found few instances of natural integration. In Philadelphia, for example, there are two neighborhoods where blacks and whites live side by side. These communities, West Mt. Airy and University City, have been integrated for over twenty-five years. While it could be credibly argued that integration does feel natural in these two areas, the rest of the city is largely organized in racially isolated and homogeneous communities.

Orfield implies in his paper's title that there is a "relationship between school desegregation and housing patterns." ${ }^{\text {" He states }}$ that we can reduce the pain of arbitrary methods of integration like busing by implementing incentives and subsidies that make it possible for blacks to live in white communities and, thereby, integrate schools naturally. ${ }^{8}$ But he and others are hard-pressed to link the improved achievement of black students to the schooling they receive in an integrated school. In Gautreaux v. Chicago Housing Authority, ${ }^{9}$

the courts ordered a set of remedies ... that permitted several thousand female-headed poor families to move out from city projects ... to suburban private units with rent subsidy certificates. The program moved the school children to vastly more competitive schools-going from the bottom quartile to the top quartile-and the city children had surprising successful and positive experiences in the schools where their presence increased integration from a very low level. ${ }^{10}$

${ }^{6}$ Orfield, Housing, supra note 1 (manuscript at 2); see Orfield, Abstract, supra note 1 , at 1405 (discussing "'naturally integrated' neighborhood schools").

${ }^{7}$ Orfield, Housing, supra note 1 (manuscript at 1); see Orfield, Abstract, supra note 1 , at 1397.

${ }^{8}$ See Orfield, Housing, supra note 1 (manuscript at 1); see Orfield, Abstract, supra note 1 , at 1405 .

${ }^{9} 480$ F.2d 210 (7th Cir. 1973), cert. denied, 414 U.S. 1144 (1974).

${ }^{10}$ Orfield, Housing, supra note 1 (manuscript at 71); see also Julie E. Kaufman \& James E. Rosenbaum, The Education and Employment of Low-Income Black Youth in White Suburbs, 14 EDUC. EvALUATION \& POL'Y ANALYSIS 229, 238-39 (1992) (concluding that the Gautreaux program had a positive effect on children's academic achievement); James E. Rosenbaum et al., Low-Income Black Children in White Suburban Schools: A 
In the scholarship of an authority on the relationship between housing and schools, one would expect more than one example of the positive effects of integration on the achievement levels of blacks. Even the example presented lacks the specificity that would allow the reader to understand exactly how integration affected academic achievement. What were the indices of success? What percentage functioned on grade level?

Nor does Dr. Orfield offer any examples illustrating the success of integration in the five most populated cities where large concentrations of minorities live. In fact, forty years after the Brown decision, ${ }^{11}$ the evidence indicates that desegregation has little or no effect on the achievement of blacks. Herbert Walberg, in a metanalysis of involuntary school desegregation programs, concludes:

Despite much hope and considerable research, despite authoritative commissions and lengthy deliberation, no consistent evidence of the positive effects of school racial composition or desegregation on Black learning has been forthcoming. Where small effects have been shown, some were positive and some were negative. The positive effects were convincingly accounted for by other explanations with clear-cut empirical support; notably, desegregated children were superior to their counterpart control groups at the outset, or were given superior instruction. Quality educational programmes, without desegregation, moreover, showed far larger effects on both Black and White learning than quality education programmes with desegregation. ${ }^{12}$

Study of School and Student Responses, 56 J. NEGRO EDUC. 35, 43 (1987) (finding that the children in the Gautreaux program "responded well to suburban schools").

${ }^{11}$ See Brown v. Board of Educ., 347 U.S. 483 (1954).

${ }^{12}$ Herbert J. Walberg, Involuntary School Desegregation Versus Effective Education, in 2 Cultural Diversity AND THE SCHOOLS 349, 363 (James Lynch et al. eds., 1992); see also Willis D. Hawley, The New Mythology of School Desegregation, LAW \& CONTEMP. PROBS., Autumn 1978, at 214, 218 (noting that out of 73 studies of particular communities that have developed explicit desegregation plans, 21 showed that desegregation had little or no effect on achievement levels of blacks, and 12 showed negative effects on achievement levels); James E. Rosenbaum, Can the Kerner Commission's Housing Strategy Improve Employment, Education, and Social Integration for Low-Income Blacks?, 71 N.C. L. REV. 1519, 1525 (1993) (suggesting that low-income black students might be permanently disadvantaged in suburban schools because "[t]heir economic backgrounds may make them less prepared or less motivated than middle-income suburban youths"); Donald R. Winkler, Educational Achievement and School Peer Group Composition, 10 J. HUM. ResOURCES 189, 190-91 (1975) (citing studies that attempt to explain why desegregation may have either little effect or an adverse effect on achievement levels of black students). 
Walberg described the lack of apparent success of involuntary desegregation efforts. Is the record appreciably better in other contexts? My experience suggests that Orfield's premise fares no better in neighborhoods that appear to be naturally integrated. I have lived in Philadelphia side by side with black neighbors for many years. We do work shifts at the local co-op together; we patrol the streets together as part of Town Watch; we organize protests to get the city to remove abandoned cars; and we promote both black and white political candidates who will better serve our community's interests.

When it comes to public schools, we make independent, although often similar, decisions. From kindergarten through third or fourth grade, $30 \%$ to $40 \%$ of the student population is white. Beyond these grades, the number of whites reduces significantly. In general, neither middle-class whites nor middle-class blacks will send their children to the local middle school. These parents, however, will either struggle to gain their children's admission to one of the magnet schools or, more likely, will find the resources to send their children to a private school. Why do residents who decide to live in integrated neighborhoods refuse to send their children to the local public school? These neighbors would answer that the quality of education is inferior. They argue that the class size is too large, the school is dangerous, and the education is not challenging.

The pattern of results in urban schools is disturbingly regular. In West Philadelphia, where the University of Pennsylvania is located, public school students leave elementary schools one to two years behind in grade level. By the ninth grade, they are two to three years behind, which explains why $50 \%$ of all Philadelphia high school students do not earn enough credits to move on to tenth grade in one year. ${ }^{13}$ And the $50 \%$ rate of retention in ninth grade is predictive of the $30 \%$ to $80 \%$ high school drop-out rates one or two years later. School districts use a variety of methods to compute drop-out rates. The most reliable method identifies a cohort of incoming ninth-grade students and follows their progress for four years. The School District of Philadelphia initiated such a cohort study for the ninth-grade class of 1984-85 city-wide. Over the course of four years, $31.6 \%$ were identified as having dropped

${ }^{13}$ See BERNARD J. MCMULIAN ET AL., Charters AND STUdENT ACHIEVEMENT: EARLy EVIDENCE fROM SCHOOL RESTRUCTURING IN PHILADELPHIA 13 (1994). 
out of school. ${ }^{14}$ Extending this study through June 1989, an analysis of the data reveals that $38 \%$ of the class was identified as having dropped out. While a $30 \%$ drop-out rate is the approximate average for the city, just a short walk from the law school that sponsored this Symposium, the drop-out rate for University City Public High School in 1992 was $73.6 \%$. At Kensington High School, of those ninth-grade students starting high school in 1988, $81.5 \%$ had dropped out by June $1992 .{ }^{15}$

Orfield might argue that if middle-class blacks and whites remained in force in public schools, the public schools would find it in themselves to meet the standards of parents who insist on high quality education for their children. In my neighborhood, residents feel comfortable about living in a racially integrated neighborhood, but they do not trust the public schools to deliver the quality of education that they think is required to make their children competitive. Their complaints, however, are not limited to the educational program. They find the schools increasingly unsafe. Drug traffic, random violence, and chronic disorder make these schools unacceptable to middle-class whites and blacks. ${ }^{16}$ Continued integration beyond the early grades is determined by the comfort levels middle-class people feel in schooling their children with poor children. The problem is not so much housing or race, but class. ${ }^{17}$ In talking about class, we do not mean caste, which is family determined and, as an ascribed status, is unalterable. Rather, we see class as an achievable status determined by education and income, and responsive to concrete effort. ${ }^{18}$ Thus, class is directly

${ }^{34}$ See Office of Accountability \& Assessment, School Dist. Of Phila., Rep. No. 9024, A STUDY OF THE NINTH-GRADE ClASS OF 1984-1985, at 1-2 (1990).

${ }^{15}$ See Dale Mezzacappa, Urban Obstacles Make Diplomas Precious at Kensington High: Their Pomp Defies the Circumstances, PHILA. INQUIRER, June 18, 1992, at B1, B4.

${ }^{16}$ See generally Dena Kleiman, Problem for City Parents: Public or Private School?, N.Y. TIMES, Oct. 18, 1981, at A40 ("Reports of violence, inferior academic possibilities and cutbacks have frightened many middle-class families away from the public school system."); Dena Kleiman, Why Many Shun City's Schools, N.Y. TIMES, Jan. 24, 1981, at B25 (reporting that "crime, truancy, overcrowded classes, and insufficient supplies" were some of the reasons why some parents did not see public schools as an option for their children); Gene I. Maeroff, Alliance for City Schools Mounts "Go Public" Drive, N.Y. TIMES, A pr. 9, 1993, at A25 (noting that there are concerns among parents about safety and achievement in public schools).

${ }^{17}$ See generally William J. Wilson, The Declining Significance of RACE: BLACKS AND CHANGING AMERICAN INSTITUTIONS 114-15 (1980) (noting that "fewer white and middle-class black parents are sending their children to urban public schools").

${ }^{18}$ See generally E. Digby Baltzell, The Protestant Establishment: ARIStoc- 
related to the number of years of schooling an individual has achieved and to the quality of that education.

\section{Education as the Primary Mover}

Christopher Jencks makes the connection between employment potential and educational level when he asserts that, the "best readily observable predictor of a young man's eventual success is the amount of schooling he has had."19 Unemployment declines and wages rise as young people move to higher and higher stages of the educational ladder. These issues are intertwined in inner-city communities where joblessness is rampant and the quality of schooling is poor. It is this deadly combination that keeps the poor stuck. William Julius Wilson draws out these implications explicitly when he states:

The net effect is that joblessness, as a way of life, takes on a different social meaning; the relationship between schooling and postschool employment takes on a different meaning. The development of cognitive, linguistic, and other educational and job-related skills necessary for the world of work in the mainstream economy is thereby adversely affected. In such neighborhoods, therefore, teachers become frustrated and do not teach and children do not learn. A vicious cycle is perpetuated through the family, through the community, and through the schools. ${ }^{20}$

The cycle is not primarily driven by race. Racial desegregation is at best a non sequitur as a policy response. How, then, do we interrupt this negative cycle of failure? What can be done to improve the quality of the educational experience for inner-city students so that they will graduate from high school and pursue postsecondary school education and training? In the nation's largest cities, education is the only credible pathway out of poverty for inner-city minorities. In the following section, I will present a program that has produced significant results for this population and may offer some guidance for policy development.

RACY AND CASTE IN AMERICA 335-44 (1964) (noting that university educations provide opportunities for Americans to elevate their social status).

${ }^{19}$ Christopher Jencks et al., Who Gets Ahead? The Determinants of ECONOMIC SUCCESS IN AMERICA 230 (1979).

${ }^{20}$ William J. Wilson, The Truly Disadvantaged: The Inner City, the UNDERCLASS, AND PUBlic POLICY 57 (1987). 


\section{THE SYTE PROGRAM}

On June 19, 1987, 112 sixth-grade students from Belmont Elementary School in Philadelphia received a historic offer from George and Diane Weiss of Hartford, Connecticut. ${ }^{21}$ The terms of the offer were that, upon graduation from high school, the students' college or vocational training tuitions would be paid in full by the Say Yes to Education Foundation (SYTE), funded by the Weisses. The model was similar to the I Have A Dream program, a relatively new type of third-party educational intervention for disadvantaged youth. Most of the Belmont students came from low-income families, and all were African-American. ${ }^{22}$ Forty-four attended special education classes, having been classified as learning disabled. ${ }^{23}$ And nine students were mainstream for most classes, but continued to receive resource room support for one or two class periods each day.

The Foundation set up a program site at the University of Pennsylvania's Graduate School of Education. Program staff consisted of me, as executive director, and two project coordinators. The Weisses and I established collaborative relationships with policy-level decision-makers at the School District of Philadelphia, with the University of Pennsylvania, and with a variety of human services providers. As students worked their way toward high school graduation, SYTE coordinators provided such services as tutoring, counseling, regular home visits, advocacy with schools, mentoring, college visitations, internships, and summer school enrichment programs. The cost of this program from grades seven through twelve averaged $\$ 1100$ per year for each student. This is a modest amount of money for the services provided and the improved outcomes discussed below. ${ }^{24}$

${ }^{21}$ George Weiss is a Trustee of the University of Pennsylvania. Diane Weiss is a member of the Board of Overseers at the Graduate School of Education at the University of Pennsylvania.

${ }^{22}$ See Dale Mezzacappa, 6th-Grade Class Is Offered a Gift of College Tuition, PHILA. INQUIRER, June 20, 1987, at 1-A, 6-A.

${ }_{23}$ See Dale Mezzacappa, Gift of Schooling May Be Hard to Accept, PHILA. INQUIRER, Nov. 1, 1987, at 1-B.

${ }^{24}$ Philadelphia spends $\$ 6513$ per pupil annually, ranking 51st out of 62 Philadelphia area school districts. The top 20 districts spend between $\$ 8268$ and $\$ 10,475$ per pupil. By adding the expense of SYTE to the Philadelphia per-pupil expenditure, the sum is $\$ 7613$, an efficient use of resources given the range of spending of the top 20 districts. See A District in Distress, PHILA. INQUIRER, Oct. 23, 1994, at G1, G8. 
The SYTE program was structured to be more than merely a vision of the future. Such concepts make little sense within the psychologies of adolescents: few students could imagine in 1987 that they might be able to take advantage of the gift in 1993 . Rather, SYTE staff built contexts for meaningful, reliable relationships with students, teachers, and students' families, developed capacities to trust, and constructed settings in which positive "possible selves" could be invented and explored. ${ }^{25}$ The staff discovered in their first meeting with the students that they were reluctant or unable to express the kind of person they wished to become. ${ }^{26}$ How did the staff discover this?

Initially, two African-American project coordinators, Randall Sims and Lily Holloway, visited each student's home to discuss the gift with their families and to interview the students about their strengths, weaknesses, talents, and interests. The coordinators picked up a wealth of information about available family supports and assessed the gaps in each family's ability to provide for their children. Over half of the parents of these children-54\% of the mothers and $47 \%$ of the fathers-did not complete high school. ${ }^{27}$ The program, therefore, was asking a large proportion of parents to help their children achieve educational goals they had not attained themselves.

Each initial student interview concluded with the following question: What would you like to be when you finish school? Fewer than $25 \%$ of all students made a response. They could not even imagine a possible future. ${ }^{28}$ They did not see their parents as role models of school success. And they, in turn, did not connect school with the ability to construct a viable future. Further, the school system they attended communicated, through its tracking and grade retention policies, that success in school was not for all children. ${ }^{29}$

${ }^{25}$ See generally Hazel Markus \& Paula Nurius, Possible Selves, 41 AM. PSYCHOLOGIST 954, 954-55 (1986) (defining "possible selves" as a "set of imagined roles or states of being").

${ }^{26}$ See Telephone Interview with Randall Sims, Senior Project Coordinator, Say Yes to Education Foundation (Apr. 1995).

${ }^{27}$ See Education Completed by Female Guardians, SYTE Data Bank, Phila., Pa. (Feb. 2, 1994) (table) (on file with author); Education Completed by Male Guardians, SYTE Data Bank, Phila., Pa. (Feb. 2, 1994) (table) (on file with author).

${ }^{28}$ See also Roberta Achtenberg, Keynote Address, 143 U. PA. L. REV. 1191, 1200 (1995) (noting that a fourteen-year-old African-American boy from Chicago's Robert Taylor Homes told HUD Secretary Henry Cisneros that "he was faced with a difficult decision: which gang to join, and when?").

${ }^{29}$ See JEANNIE OAKes, KeEPING TRaCK: How Schools Structure INEQUaltTy 3 
And, more precisely, not for them. Minority students from lowincome families were particularly at risk for subject failure, retention in grade, and, finally, dropping out. These policies depress students' interest in school and academic pursuits. They feel devalued and, as a result, become alienated from school. In Claude Steele's terms, African-American students from low-income families "disidentify" with school as the place that can help them. ${ }^{30}$

The SYTE program set out to create an alternative vision of the future for SYTE students, their families, and the schools they attended. The ensuing years of the staff's careful support required students to work hard, to be persistently motivated to succeed, and to believe that education could make a positive difference in their life opportunities. The SYTE staff was responsible for communicating the vision and translating its meaning into the incremental steps that students had to take to achieve their goals.

A deep relationship developed between staff and students. In April 1993, I interviewed a female student who captured the level of mutual trust in the following way:

You all [staff] are not just people who are like our friends. We can talk to you. We go out to lunch and dinner with you. It's like you are older friends, more than counselors and coordinators. It's a different kind of feeling. You all listen. Most people don't listen. You all listen.

In addition to the ongoing advocacy and counseling of students, the program sponsored extensive tutoring opportunities. Students recruited from the University of Pennsylvania and other area colleges tutored SYTE students during after-school hours. When students were attending high school and needed to work after school, staff made arrangements with the Penn Bartram School for Human Services, where over half the students were enrolled, for tutors to be available all day. As a demonstration of outreach to the whole school population that all the students' successes in school were also valued by the program, SYTE installed 100 tutors available to the entire student body. In public schools, essential services like tutoring can be scarce or limited. Although it was not always possible to offer SYTE's resources to all students, the program was

(1985) (observing that when children are grouped in a public way by their intellectual capabilities, "these groups are not equally valued in the school").

${ }^{30}$ See Claude M. Steele, Race and the Schooling of Black Americans, ATLANTIC MONTHLY, Apr. 1992, at 68, 74-75. 
deliberately extended beyond itself to promote tutorial assistance for all who needed it.

The SYTE program tried to model the kinds of activities that need to be implemented if more inner-city students are to succeed. Therefore, in addition to providing tutoring for all students, SYTE upgraded the work-study component of the school by recruiting a full-time volunteer to develop higher quality job placements for all students. Similarly, prior to SYTE's involvement, the Penn Bartram School for Human Services only offered its students a brief SAT preparation course consisting of eight forty-five-minute sessions over one month. SYTE, in contrast, sponsored an intensive program over three months with a forty-five-minute session twice each week. The program brought in an outside specialist experienced in training students for the test. This program disclosed some of the weaknesses in the academic preparation of students, especially in vocabulary development.

The principal, observing the SAT class, felt defensive at first when he saw students' scores on practice tests. He claimed "our students do not do well in this kind of test"-an allusion to the alleged bias in the vocabulary students are expected to know. Midway into the course, the principal instituted a school-wide campaign to strengthen vocabulary acquisition. Teachers introduced new words and reinforced their usage in all basic subject classes. The SAT course was one more example to the faculty and administration that SYTE had high expectations for its students. If SYTE students were experiencing more pressure to succeed, teachers, too, were experiencing pressure to improve the quality of education, so that more students would be successful in their academic subjects.

The staff carefully monitored students' grade performances. Regularly scheduled meetings with the students' classroom teachers, counselors, and administrators were held to assess student progress and to explore alternative methods of instruction when that seemed necessary. If SYTE was going to change the odds for student success, the staff believed that a comprehensive approach was essential: one that combined an array of social supports, academic monitoring, advocacy for school reform, and deep parental involvement.

The staff also met monthly with the parents to discuss topics concerning their child's development such as discipline, teenage sexuality, communicating with school officials about their child's progress, and setting and reaching goals for the future. With the 
parents of children in special education, the project coordinators organized a series of workshops conducted by parents who had faced similar problems in accessing appropriate services for their children's special needs. Parents were also involved in planning and cooking for holiday celebrations, implementing outreach to disaffected families, chaperoning student trips and events, and representing the program in public fora. Over the six years, whenever a student was in some kind of difficulty in school, the first intervention was a home visit to assess how the family was coping with the problem. When parents were not able to help their child, the staff took on surrogate parental responsibility by advocating for better placements in school, accessing needed social, medical, or academic services, and mediating family conflicts.

The transitions from elementary to middle school and from middle to senior high school are often fraught with danger. For students with academic difficulties, the transition to an unfamiliar environment and the different expectations of a new school for which they have not been prepared aggravates already existing problems. $^{31}$ Each of these school-level transitions for SYTE students was a disastrous experience: $23 \%$ of the students were retained in seventh grade, $30 \%$ in ninth grade. ${ }^{32}$ Both statistics, however, were lower than city-wide averages. For example, at Bartram and University City High Schools, two of the comprehensive high schools that SYTE students attended, respectively, $35 \%$ and $52 \%$ of all ninth graders were retained. ${ }^{33}$ There is evidence suggesting that the cause of these precipitous drops in achievement may be associated with a mismatch between the structure and organization of school levels, which put large numbers of students at risk. ${ }^{34}$

${ }^{31}$ See Jacquelynne S. Eccles \& Carol Midgley, Stage-Environment Fit: Developmentally Appropriate Classrooms for Young Adolescents, 3 RES. ON MOTIVATION EDUC. 140 (1989) (arguing that a variety of changes that coincide with the transition to junior high school may contribute to changes in students' motivation and achievementrelated beliefs); Norman A. Newberg, A Systems Approach to School Reform, in THE Reflective TuRn: CASE Studies IN AND on Practice 53, 53 (Donald A. Schön ed., 1991) (discussing the need to address the "complex needs of students who must adjust" to the transition from a lower school to a higher one).

${ }^{32}$ See Student Retentions by Grade as of August 1993, SYTE Data Bank, Phila., Pa. (Feb. 2, 1994) (table) (on file with author).

${ }^{39}$ See Superintendent's Management Info. Ctr., School Dist. OF Phila., REPORT NO. 9021, at 98,158 (1990).

${ }^{34}$ See, e.g., Jacquelynne S. Eccles et al., Development During Adolescence: The Impact of Stage-Environment Fit on Young Adolescents' Experiences in Schools and Families, 48 AM. PSYCHOLOGIST 90, 91-97 (1993) (discussing stage-environment fit and schools); 
Generally, students disperse to a variety of settings for high school. The SYTE leadership felt that it would be helpful to concentrate a substantial proportion of its students in a small, caring school so that academic and social development could be supported. I created an alternative to large comprehensive high schools in 1972, the Penn Bartram School for Human Services, which had a reputation for knowing how to shepherd a class of students through high school. The Penn Bartram School for Human Services, an annex of the Penn Bartram Senior High School main campus, included students from grades ten through twelve. The program's sponsors and I convinced the school district to expand the school to include ninth grade and invited SYTE students to form the first freshman class.

Thus, SYTE became a program that attempted to change the context of school and the odds that defeat inner-city students' success. In a sense, the program was much more than a gift that changed the opportunity structure for students from low-income families. The program was making a critical point: that without transforming relationships and a widening of their senses of possibility, students would not be able to take advantage of better opportunities.

\section{RESEARCH DATA}

Little research has been reported about tuition-guarantee programs and the effects on those who participated. ${ }^{35}$ These programs are unlike Head Start, which provides a twenty-five-year track record to examine and on which multiple studies have been conducted. Programs like SYTE are works in progress. Further research will need to be conducted before we can determine definitely the efficacy of these programs. But we can provide interim indications that are encouraging by comparing the SYTE data to a group of students who were one year ahead of the SYTE population. The comparison group attended the same elementary school as the SYTE students and followed the feeder patterns of

Michelle Fine, Chartering Urban School Reform, in Chartering URBan School REFORM: REFLections ON PUBLIC High SCHOOLS IN THE MIDST OF CHANGE 5, 5-30 (Michelle Fine ed., 1994) (explaining the charter program in Philadelphia high schools).

${ }^{35}$ See generally U.S. Gen. Accounting Office, Promising Practice: Private Programs GUARANTEEING STUDENT AID FOR HIGHER EDUCATION (GAO/PEMD-90-16, 1990). 
schools in their neighborhood through high school. The comparison group also reflected a similar socioeconomic background.

By August 1993, forty-four SYTE students graduated from School District of Philadelphia high schools. An additional five students received high school diplomas or Graduate Equivalency Diplomas from private or out-of-state schools. By December 1994, twelve more had graduated, bringing the total to sixty-one graduates. Three students were deceased. One hundred eligible SYTE students were compared with a group of eighty students with similar backgrounds. ${ }^{36}$ The results indicated that $44 \%$ (forty-four students) of the SYTE group and $28 \%$ (twenty-two students) of the comparison group completed high school. The difference is significant at the $p<.05$ level. ${ }^{37}$

Comparing graduation rates of all male students in SYTE to the males in the comparison group, the results were $46 \%$ and $22 \%$ respectively $(p<.05)$; for females it was $43 \%$ compared to $34 \%$. These data showed that SYTE male students did significantly better than the males in the comparison group, but there was no significant difference in the female groups. ${ }^{38}$

When the regular education students were disaggregated from the special education population, the data showed that $61 \%$ of the SYTE students and $32 \%$ of the comparison group graduated $(p<$ $.01)$. The drop-out rates for the two groups also differed: $36 \%$ for the SYTE students and $54 \%$ for the comparison group. ${ }^{39}$ And for regular education students, the drop-out rate was $20 \%$ for the SYTE students and $50 \%$ for the comparison group $(p<.01)$. Thirty-nine matriculated to colleges, and six went to trade schools. ${ }^{40}$

${ }^{36}$ Twelve SYTE students and five comparison group students were excluded from this analysis. These students were excluded because they moved from Philadelphia, transferred to a parochial or private school, had incomplete records, or are deceased.

${ }^{37} P$ is used here as a t-test value and indicates the degree to which the results can be attributed to chance.

${ }^{38}$ The low graduation rates for the females may be attributed to the fact that $50 \%$ of the SYTE females delivered babies by age 16 . No comparable statistics exist for the comparison group.

${ }^{39}$ See Michael D. Schlesinger, A Study of a Tuition Guarantee Program 125-33 (1993) (unpublished Ph.D. dissertation, Temple University) (summarizing the findings of a comparison done to evaluate the effectiveness of the SYTE program in reducing the number of student dropouts).

${ }^{40}$ Postsecondary school information about the comparison group is not available. Until 1994, the School District of Philadelphia recorded only a student's postsecondary intentions, but not their acceptance to attend a particular institution. 
To what can we attribute these gains? Institutional contexts make a difference. School size and faculty commitment to students and their learning are key factors in helping improve the performance of students from low-income families. ${ }^{41}$ Researchers have been reporting that large, impersonal schools are inappropriate settings for children. Over the last five years, efforts have been made in several cities to restructure comprehensive high schools into smaller units called "charters." In Philadelphia, over 100 charters have been established within existing high schools. Results over four years indicate improvement in attendance and subjects passed for students in charters, ${ }^{42}$ who performed substantially better than those in a control group.

The SYTE program constructed an ecological system for raising children that society has placed at risk. Central to this effort has been the continuity of caring provided by SYTE for more than six years. It acted as a third-party advocate and broker for students between and among these various systems. Its advocacy was goaldirected, improving the quality of life for each student through education.

Initial interviews with SYTE students noted that less than $25 \%$ could describe what they wanted to become after finishing school. Children who live in poverty do not grow up imagining positive "possible selves." ${ }^{43}$ They are locked into limited, often negative self-concepts. Programs like SYTE make a difference by expanding children's aspirations and by providing support for their realization.

I agree with Orfield that desegregated neighborhoods and schools can produce social contexts that are beneficial to all races. But that eventuality does not obviate educators of the responsibility to improve substantially the quality of schooling for inner-city minorities. The fate of poor black students, therefore, is linked to the high quality of education they receive in the schools they attend and sustained support of caring adults. It is this combination that may produce a generation of citizens whose skills and knowledge will be competitive enough so that they can make better life choices.

1 See Diana Oxley, Organizing Schools into Small Units: Alternatives to Homogeneous Grouping, 1994 PHI DELTA KAPPAN 521, 526 (commenting that "teachers need to reorganize existing academic tracks and special needs programs and to adopt instructional methods that allow them to meet diverse student needs ${ }^{n}$ ).

\$2 See MCMULLAN ET AL., supra note 13, at 7-9.

t3 See Markus \& Nurius, supra note 25, at 954-55. 
